\title{
The Research on the Reflective Teaching Mode of Backbone Teachers Participating in the "National Training Plan"
}

\author{
Zhen Zhou \\ Foreign Languages College, Nanchang Normal University, \\ Nanchang, Jiangxi, 330032 \\ zoye100@sina.com
}

\begin{abstract}
Keywords: Backbone teachers; Reflective model; Practical reflection; Cognitive reflection; Affective reflection.
\end{abstract}

\begin{abstract}
The Reflective Teaching is the most effective way to promote teachers' professional development. And The Reflective Teaching mode is an important pattern of the teachers' professional development. At present, the effect of the rural primary and secondary school English backbone teachers training which belongs to the "national training plan" is not ideal, and there are many problems. Thus this paper explores a new reflective model, namely, PCA Teaching Reflection Model (practical reflection, cognitive reflection and affective reflection), from the aspect of the teachers participating in the training, to promote teachers' professional development, and to further improve the training effect of the rural primary and secondary school English backbone teachers.
\end{abstract}

\section{Introduction}

"The training project of the middle and west rural backbone teachers in the primary school and middle school" is the sub-item of "National Training Plan". It means that from 2010, under the macro planning and guidance of the education department and the finance department, the central finance appropriates special fund to support the middle and west provinces to carry out suitable training on the teachers working in the rural compulsory education according to the global requirement of "National Training Plan". The training plan mainly includes the replacement training of rural primary and middle school teachers, the short-term concentration training, and distant training.

In 1980s, it became a hot issue to research into the reflective teaching in the field of education. But until today, the definition of teaching reflection is still variant, which can not reach an agreement. Some scholars think that teaching reflection starts from exploring and solving teaching problems, and it is motivated by pursuing the reasonability of teaching practice. The reflective teaching is the all-around development of teachers themselves. Teaching reflection covers a lot of content, not only including the consideration of their own knowledge, behavior, but also the reflection on social, moral and political factors. The teaching reflection is vital to teaching, which is the most effective channel and one of the core factors to promote teachers' professional development. The American educator Poisoner puts forward the famous formula: Teachers development= experience+ reflection, that is, the experience without reflection is skin-deep and narrow knowledge. Ye Lan also points out that a teacher can not be a famous teacher if he keeps writing the teaching plan for a whole life. But if a teacher keeps writing the teaching reflection for 3 years, he may become a famous teacher.

Some scholar and experts also do researches into reflective teaching mode and has gained some meaningful result. Wallace puts forward the recycling reflective teaching mode of reflecting on the professional knowledge and experience. Jin Min employs reflection notes to study the training of reflective English teachers. Hui Yan explores school-based teaching research and training mode of the primary school based on practice and reflection. Lu Shufang points out that the interactional English teacher school-based teaching mode.

But at present, "National Training Plan" of rural primary and middle school backbone teachers often take forms of expert lectures and demonstration lecture. And the trained teachers are very passive and could not actively reflect on their own teaching ideas and behavior, nor do they have 
strong professional development desire. Therefore, the effect of "National Training Plan" is greatly restricted and impeded. Thus, the article attempts to improve the efficiency of backbone teacher training through exploring the reflective teaching mode of backbone teachers participating in "National Training Plan" in Jiangxi Province.

\section{PCA Reflection Mode (Practical reflection-Cognitive Reflection-Moral Reflection)}

Practical Reflection. Truth comes from practice, and knowledge originates from practice. And the teaching practice provider valuable experience and resource for the teaching reflection. The teacher's professional development is a recycling and repeating process with constant practice, reflection, cognition and practice. The teachers' practical reflection can make teaching experience theoretical, make teaching methods systematic and scientific, can let teachers discover problems in time and solve them effectively, which can improve teachers' class teaching effect, and can promote teacher's own teaching theoretical level and practical teaching level as well. Teachers' practical reflection is actually a process to nurture some creative development on the teaching practice.

Teaching Journals and Notes. The teaching journals include the teacher's analysis of the teaching process, implementing effect, and the key details of class teaching. The teacher's journal is the teacher's everyday "self-talk", which is an effective way to know their own teaching ability. The teaching notes refers to it that, in the practical teaching, the teacher takes the form of reflection to write down his personal understanding and feelings of the practical teaching, in order to monitor and control themselves easily and conveniently. The teaching journals and notes are easy to carry and read, and the teacher can discover some teaching rules, and find out blind teaching points or mistakes. The trained backbone teachers can keep writing the teaching journals and notes, and transfer their feelings from the theme lecture, demonstration teaching, and shadow teaching to tangible words.

Network Teaching Reflection. Nowadays, in this explosive mass data information era, the strong function of network communication is tremendous which can break the restrictions of time and space, and realize world-wide real-time convenient communication. Therefore, teachers can catch up with the pace of time, make full use of media, such as, network, journals, blogs, web-pages, discussion group, seminars, we-chat and e-mail, to reflect or make a record of their teaching feelings and understandings and communicate with other teachers concerning the teaching reflection. Besides, teachers can design some specific problems based on the particular content of every lesson, and try to solve them and exchange effective and wise teaching design and teaching management methods.

Observing Other Teachers' Class. Observing other teachers' class is the basis and ladder for a teacher to grow up, which is also a good chance for a teacher to learn, reflect and develop. Other teachers' teaching behavior can reflect different teaching and educational ideas, which is of great reference and significance. During appreciating other teacher's class, through communication, teachers can acquire teaching inspiration, and further reflect on themselves and rebuild their own teaching theory and practice system. But it can not be neglected that many teachers only take observing other teachers' class as a superficial form, so the effect is not so satisfactory. The key reason is that many teachers only listen to the class, but never think twice or reflect. Therefore, the teacher should improve their observing level and efficiency, observe every class carefully and reflect carefully. Only in this way, can the teachers' teaching abilities be promoted, individualized and eventually can they achieve a lot.

Demonstration Teaching Reflection. Demonstration teaching reflection, which is also called open teaching, is a teaching organization form to explore the teaching rules, research and reform teaching content and methods, evaluate or promote the teaching experience and to carry out teaching and research activity. To organize demonstration teaching reflection teaching requires a teacher to have a very clear research purpose and plan. And after appreciation, the teachers should discuss about the class teaching and do some researches. In the backbone teacher training, the teaching appreciation of "The same class, different design ideas" is a good way for teachers to reflect. After the teachingappreciation, the famous teacher who teaches the open class should also make some assessing 
reflection. The teaching reaction should be purposeful, specific and should not be too general or too wide in scope. Besides, the teaching- appreciation mainly refers to learning and drawing teaching experience and teaching skills from other teachers' teaching process. After the teaching appreciation, the teachers should keep a record of the teaching appreciation, summarize the teaching content and characteristics and reflect.

Video Teaching Reflection. The teacher's teaching video can completely record the teacher's class behavior, and can display the detailed problems in the teaching procedure as well. Through watching the teaching video, the teacher can know their own teaching advantages and shortcomings clearly. It is a very effective way to take advantage of the class teaching video to make the teaching reflection, which is of great importance to improve the teacher's teaching and educational level and promote teacher's professional development. The backbone trainee teachers can video-tape their own teaching in groups, and the teacher himself or his colleagues can watch the class teaching video, and then research, assess and discover the problems in the class teaching process, discuss the causes of the problems, find out solutions and improve the teacher's professional teaching level.

Action Research Reflection. The action research is an important way for a teacher to reflect on his lessons. In the practical English teaching process, the teacher can carry out "action research" centering on the class teaching, study, reflect, summarize and grasp students' ideas and feedback, and combine action and research, integrate teaching and researching, in order to promote the teacher and students to improve together. The specific stage of the action research as follows: a. To consider and set research questions; b. To gather related literature review materials circling the researched questions; c. To put forward hypothesis based on the literature review reading and researching and make the action plan; d. To carry out the research activity according to the new plan and make necessary adjustment, according to the teaching practice; e. To gather researching information and write the research report or teaching paper.

\section{Cognitive Reflection}

To Learn the Theoretical Knowledge. It is often a common phenomenon to divide teaching and practice. Normally teachers have rich experience, but lack the guidance of scientific theory and many teachers only stay at the understanding of experience to understand the teaching and education. If the teacher wants to improve themselves, and to transfer experience level to scientific level, they should learn the teaching theory, explore and practice teaching theory constantly and cultivate their critical thinking ability. The teaching practice can not be divorced from the teaching theory. Therefore, teachers should combine theory and practice together, be armed with scientific theory, constantly innovate teaching ideas and further enhance their professional level.

To Take Part in Teaching Seminars. The teaching seminar is a meeting themed with academic topics aiming at facilitating academic exchange and project research, which is authoritative, pioneering, pragmatic and directive. Since the backbone primary and middle school teachers teach in the countryside, they lack the newest information. Hence, they can take part in some academic seminars and research the hot issues in the teaching practice, share the research methods and result of language education, study and communicate theoretical and practical problems, and know about the recent researches, broaden their horizons, accumulate new methods, realize the sharing of quality teaching resource and promote teacher's professional development eventually.

\section{Affective Reflection.}

Reflection on the Teacher's Level. To be a teacher, one should not only transmit knowledge, but also nurture students' mind. The teacher should act as a good role model. The teacher's values indirectly influence students' character building and healthy development. Therefore, the teacher should use scientific Marxist values to arm themselves, uphold positive and accurate values. The teacher should think about good people, good deeds and unjust social cases, spread tolerate and 
democratic values, advocate positive power in the teaching practice, and do not mislead students and do not teach students to be snobbish, lazy, flattering and cynic.

Reflection on the Teacher's Teaching Belief. The teacher's teaching belief is the teacher's opinion on the teaching practice, students, study, teaching curriculum, teaching environment and teacher's role, which greatly influences the teacher's cognition on the teaching context, decision of the curriculum and teaching, and on the choice of teaching methods. "Teacher's morality", that is , the teacher's professional morality, which belongs to the teacher's belief, means the norms and behavioral maxim the teacher should conform to in the teaching practice, and the corresponding moral conception, upbringing and traits. As for a teacher, he should always consider the significance of the teaching profession, reflect whether they are students' role model, and try to be a good moral model.

Listen to Students' Words from Their Heart. For a reflective teacher, his primary task is to study the learning situation, and research students' background. The communication between the teacher and students is an art and also is the core of teaching success. Listening to students' heart and being insightful to students' real thoughts is the key to carry out effective teaching. When listening to studentship heart words, the teacher should not be too authoritative to lecture them. The teacher should learn to be a good listener, and he should have sharp eyes to observe students' heart. And the teacher should communicate with students to know students' family background, learning style, hobbies, interest, learning feelings, learning confusion and know students' favorite class activities. Especially, when the teacher finds some students feel low or separated by other students, the teacher should chat with them heartily, encourage them and offer some help.

\section{Conclusion}

The teaching reflection is one of the core factors of teacher's professional development, and is also the most effective channel to promote teacher's maturity. And the teaching reflection can solve the problem of separating the teaching theory and practice in China's primary and middle school English teaching. This article mainly explores the reflective teaching model of PCA, which is of great theoretical value and practical significance to boost the teaching quality of rural primary and middle school English teaching.

\section{Acknowledgements}

This work ws supported by the 2012 key project of educational science planning of Jiangxi Province (Project name:The exploration into the training mode of rural backboe teachers in the primary and middle school of "The national planning" in Jiangxi Province, 12ZD012); 2105 high quality resource sharing course "English teaching and research" of Nanchang Normal University.

\section{References}

[1] Akbari R. Reflections on reflection: A critical appraisal of reflective practice in L2 teacher education [J]. System 35: 2007, 192-207.

[2] Akbari R., F Behzadpoor \& B.Dadvand. Development of English language teaching reflection inventory [J]. System 38: 2010, 211-217.

[3] Bailey K. M., A. Curtis \& D. Nunan. Pursuing Professional Development: The Self as Source [M]. Boston, MA. Heinle \& Heinle. 2001.

[4] Richards J. C. \& T. C. Farrell. Professional Development for Language Teachers [M]. New York: Cambridge University Press. 2005.

[5] Wallace M. Training Foreign Language Teachers: A Reflective Approach [M]. Cambridge: Cambridge University Press, 1991. 
[6] Lu Shufang. The multiple interactive English teachers' school-based educational model with the goal of developing teacher's reflective ability, J. Journal of Inner Mongolia normal university (Educational Science).2014. 